\title{
REGIONAL PECULIARITIES OF THE PANDEMIC IN GEORGIA AT THE INITIAL STAGE OF THE CORONAVIRUS
}

\author{
AVTANDIL SULABERIDZE \\ Doctor of Economic Sciences, Professor \\ The Institute of Demography and \\ Sociology Ilia State University, Georgia, \\ Academician of the Georgian \\ Academy of Economic Sciences, Georgia \\ sulaberidzeavtandil@gmail.com
}

\section{JOSEPH ARCHVADZE}

\author{
Academic Doctor of Economics, Professor \\ Kutaisi University, \\ The Institute of Demography and \\ Sociology Ilia State University, Georgia \\ daswreba@yahoo.com
}

\author{
NINO GOMELAURI \\ Associated Researcher \\ The Institute of Demography and \\ Sociology Ilia State University, Georgia \\ nino.gomelauri@iliauni.edu.ge
}

\begin{abstract}
Aspects of behavior and functioning of every state, social institute, human are rapidly changing in the modern world. The pandemic occurring at the current stage of societal life has had an essential impact on the development of the society. This was reflected in the changes of humans' sociological, economic, psychological, educational, cultural and other types of behaviors. In the fight against the global pandemic we notice a societal regress and therefore a wide study of the societal losses caused by the pandemic and coming up with preventive measures on the global as well as regional scale occupy an important place on today's agenda. Gradually, an opinion to the effect that the world will change and never be the same takes root in a society. Consequently, scientists must answer the following questions coming from the society: how will the coronavirus develop and reach its end, will there be other waves of the virus and how much more dangerous can they be compared to the first one? What will be the new format of the fight against it? How will economy, education, science and culture develop? What kinds of risks and threats are expected to rear up in the world, on its certain continents, countries, etc.? The issue is all the more pressing and urgent not only because of the display of the pandemic's peculiarities today and in the previous period with regard to various fields of societal development, but also as a result of the need to analyze the possible scenarios and trends of the post-pandemic period in regional perspective. The above-mentioned indicates the necessity of establishing the newest interdisciplinary field of science - pandemology. The fact of the matter is that as opposed to the existing science field of epidemiology, the research object of pandemology is broader and is derived from the global character of pandemics. Epidemiology belongs to the sphere of medicine whereas pandemology has to study not only medical domain but also the consequences caused by economic, demographic, sociological, psychological and other types of behavioral changes itself occasioned by the pandemic on the global scale as well as differentially, according to certain continents and countries. In this regard, we present regional peculiarities of the results of a research conducted in some fields of pandemology, namely, sociology of pandemics and economy of pandemics in Georgia at the initial stage of the coronavirus. Against the background of risk perception and knowledge of the threat of pandemic, the article discusses the self-preservative preventive behavior of the population. It further analyzes the results of the population's self-caring and economic behavior under those social-economic conditions which are brought about by the pandemic.
\end{abstract}

KEYWORDS: PANDEMOLOGY, REGIONAL PECULIARITIES, CORONA SOCIOLOGY, CORONA ECONOMICS, ECONOMIC AND SELF-PRESERVATIVE BEHAVIOR.

For citation: Sulaberidze, A., Archvadze, J., Gomelauri, N. (2021). Regional Peculiarities of the Pandemic in Georgia at the Initial Stage of the Coronavirus. Globalization and Business, №11, 25-34. https://doi.org/10.35945/gb.2021.11.003

\section{INTRODUCTION}

In our opinion, due to the specific character of the qualitatively new pandemic, there should be established pandemology as the newest field of science with its relevant special disciplines. The urgency of the establishment of pandemologyas a scientific disciplineis strengthened by the opinion of medics, who believe the $21^{\text {st }}$ century to be the era of epidemics and pandemics. Therefore, other types of epidemics and pandemics with different designations might surface 
in future. However, using the knowledge accumulated as a result of studying pandemology, we will be better prepared to face new massive viral infections and accordingly, societal losses will be reduced to a minimum.

Regionalism, general theory of pandemology and the methods of its various fields ${ }^{1}$ in tandem with sociological, psychological, demographic and economic methods of analysis appear to constitute the main theoretical-methodological basis for studying a pandemic. Together with the formulated theories in certain fields of societal science in previous years, the main theoretical-methodological basis of the general theory of pandemology itself is built upon the theories of epidemiological (Omran, 1971) and health transition (Tsuladze, ..., 2015) and the concept of pathocenosis (Grmek, 1994) which were advanced after the 70 s of the twentieth century. If the previous two theories are directed at explaining century-old and large scale evolutionary changes in morbidity andmortality, the theory of pathocenosis, in contrast, more or less, specifies the results of the spread of epidemics and pandemics in relatively short historical periods and presents the losses caused by the various types of pathocenosis in certain periods of mankind's existence.

It is noteworthy that the periodization of all three theories is, more or less, similar to each other, which makes it easier to study pandemics. With the help of these theories, apart from the historical study of the previous pandemics, we can answer the questions concerning the current pandemic: how will the pandemic develop and what risks and threats are to be expected? Determine the periodicity of repetition and mutation prognosis, what kind of fight management format must be employed against it, etc.

Since 2020 in Georgia as well as throughout the world certain fields of science started to deal with the issue of the pandemic (coronavirus) by putting forth articles and researches. In this regard, within the scientific works of economists we cannot iceeconomic views related to Coronavirus. V. Papava and V. Charaia (Papava, ..., 2020) state that until now the economists have been studying the impact of an economic crisis on health care system generally. The present situation in the world has cast the issue in a different light, namely, that Coronavirus and its global spread is already causing a largescale economic crisis (Geller, 2020), and that Coronavirus has practically transformed into the "economic pandemic" (Riley, 2020). In their opinion, the relevancy of Coronanomicsis determined not only by the fact that today we have a full-blown declared Coronavirus pandemic, but also that these types of global threats, supposedly, will not be accepted in the future and under these conditions, the world must learn to live and continue its economic activity (Gigerenzer, 2020).

The works of the Georgian economists are related to

\footnotetext{
${ }^{1}$ Science fields of the interdisciplinary pandemology are distinct and thus, together with their general methods of research, they have their own specific methods and methodology. For example, economics, sociology, demography, psychology, geography, etc. of pandemic. This enables us, with regard to certain fields and periods, to manifest and analyze general as well as specific peculiarities of the pandemic and formulate preventive measures of management for possible future pandemics and epidemics (Sulaberidze A. 2020).
}

the problems of Coronaeconomics. These are the mentioned scholars: V. Papava (Papava, 2020), A. Tvalchrelidze and A. Silagadze (Tvalchrelidze, Silagadze, 2020), E. Mekvabishvili (Mekvabishvili, 2020), R. Abesadze (Abesadze, 2020), M. Jibuti (Jibuti, 2020), V. Charaia (Charaia, 2020), G. Bedianashvili (Bedianashvili, 2020) and others.

Interesting researches were carried out in the direction of the sociology of the pandemic (Beck, 2020, Cohan, 2020, Prince Kennex R. Aldama 2020, Capriano, 2020, Fitzpatrick, 2020 and others).

\section{DATA AND METHODS}

The aim of the sociological research conducted by the Ilia State University's Institute of Demography and Sociology in October, 2020 was to study the levels of awareness, self-preserving and social-economic behavior of the population in Georgia and some of its cities with regard to the coronavirus pandemic and furthermore, to assess the impact of the pandemic on the social-economic situation of the Georgian population.

Under conditions of a pandemic it is of special significance for a healthcare system to work without a hitch, the share of the aged and elderly within a demographic structure (level of demographic aging) and health condition of a population are also important. The totality of all three factors significantly determines the risk of becoming infected and lethality of the virus. As a consequence, all of these factors were taken into consideration during the research of the pandemic. In view of the research methodology, along with a sociological questionnaire, we have used an in-depth interview. The following cities were selected: Tbilisi (a big city), Kutaisi (a medium-sized) and Khashuri (a small city). During the selection process we took into account the current level and risks of the spread of the coronavirus, seasonality (tourism and resort period), demographic-geographical factors (sexage structure and the level of demographic aging, migration, distance between the populated areas, etc.). As a result of the above, the number of the respondents was determined to amount to 500 individuals, among whom we interviewed 250 in Tbilisi, 150 in Kutaisi and 50-50 respondents in Batumi and Khashuri. Considering the risk of the coronavirus's spread rate, the respondents were selected from three aggregate age groups: below 21 years of age $-20.4 \%$, between $21-60$ years of age $-58.5 \%$ and above $60-21.1 \%$.

The majority of the interviewed people were women - 57.7\%. The interview was anonymous and we adhered to the recommendations of the Georgia's Ministry of Health (social distancing and necessity of wearing masks). One of the hindrances to the research was the election period (5-15 October).

\section{RESULTS OF THE RESEARCH}

Some corona sociological aspects of the population's self-preservative behavior

One of the factors of the spread of the pandemic is deemed to be self-preservative behavior of a population, 
Figure1. Distribution of the interviewed individuals according to the 5 point system as per the aggregate age groups of the respondents and cities

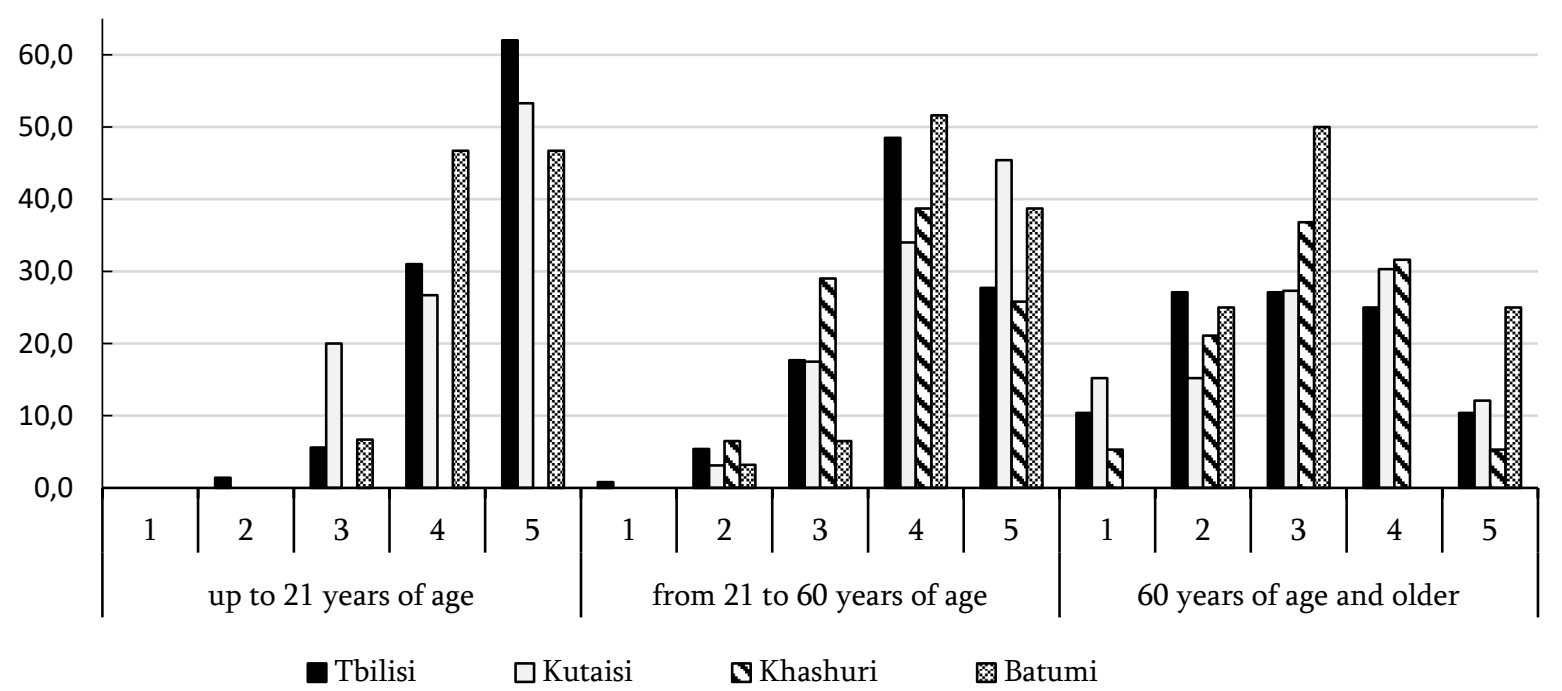

which much determines their health condition. Accordingly, our object of interest, first and foremost, was the general health condition of the interviewed respondents at the initial stage of the coronavirus which we assessed using a five-point system: 1 - Very bad; 2 - Bad; 3 - Medium; 4-Good; 5 -Very good. Figure 1 makes it clear that, from the standpoint of the health condition of the respondents, the age group below 21 years of age gave the best assessment. Their health condition indicator is the highest (5 points). Tbilisi stands out especially, after which followed Kutaisi and Batumi. It must be noted that the sum of 4 and 5 point health indicators in Batumi significantly exceeds the analogous indicator in Tbilisi and Kutaisi. As regards the respondents from Khashuri, even the small number of the selected individuals within the mentioned age group found it difficult to self-assess their own health condition.
As opposed to this age group, it is striking, in contrast to individuals from the other cities, that the indicator of self-assessment is low ( 3 points) among those aged from 21 to 60 of Khashuri. Moreover, if their self-assessment is quite high on the 3-point level as compared to the analogous indicator of the other cities, we cannot say the same for the indicators of Khashurians on the 4 and 5-point levels, which are relatively, low in comparison with the other cities, especially on the 5-point level.

It is known that, under conditions of a pandemic, the elderly individuals belong to the group with the highest risk of potential infection. In this regard, following the results of the interview aimed at individuals aged above 60 , those from Batumi emerged to have the smallest risk of becoming infected. The biggest and medium indicators of self-assessment of their health ( 5 and 3 points respectively) were the highest. It

Table 1. Self-assessment of their health by the respondents using the 5-point system, according to sexes and regions (\%)

\begin{tabular}{|c|c|c|c|c|c|c|}
\hline & \multicolumn{5}{|c|}{ 5-point system of self-assessment } & \multirow[t]{2}{*}{ Total } \\
\hline & 1 & 2 & 3 & 4 & 5 & \\
\hline $\begin{array}{l}\text { Total number of the } \\
\text { interviewed } \\
\text { individuals }\end{array}$ & 2.4 & 7.5 & 18.2 & 37.4 & 34.4 & 100.0 \\
\hline & \multicolumn{6}{|c|}{ Male } \\
\hline Tbilisi & 2.9 & 7.4 & 16.9 & 43.4 & 29.4 & 100.0 \\
\hline Kutaisi & 2.4 & 7.3 & 23.2 & 34.1 & 32.9 & 100.0 \\
\hline Khashuri & 3.1 & 12.5 & 31.3 & 34.4 & 18.8 & 100.0 \\
\hline Batumi & 0.0 & 0.0 & 5.7 & 51.4 & 42.9 & 100.0 \\
\hline \multirow[t]{2}{*}{ Total } & 2.5 & 7.0 & 18.9 & 40.7 & 30.9 & 100.0 \\
\hline & \multicolumn{6}{|c|}{ Female } \\
\hline Tbilisi & 1.8 & 9.7 & 15.0 & 33.6 & 39.8 & 100.0 \\
\hline Kutaisi & 4.8 & 3.2 & 15.9 & 30.2 & 46.0 & 100.0 \\
\hline Khashuri & 0.0 & 11.1 & 33.3 & 38.9 & 16.7 & 100.0 \\
\hline Batumi & 0.0 & 13.3 & 20.0 & 33.3 & 33.3 & 100.0 \\
\hline Total & 2.4 & 8.1 & 17.2 & 33.0 & 39.2 & 100.0 \\
\hline
\end{tabular}


is true that Khashurians' health self-assessment indicator on the levels of 3 and 4 points exceeds the aged population of Tbilisi and Kutaisi, however, it lags behind the latter's health self-assessment indicator on the level of 5 points.

As table 1 demonstrates, nearly third of the respondents assess their health as good or very good, and each of these indicators exceeds the total number of those respondents who assessed their health as being very bad, bad and medium. It should be mentioned that, from this viewpoint, the health self-assessment indicators of men on the medium (3 points) and good (4 points) levels are comparatively better that the analogous indicators of women and outstrip the latter by $1.7 \%$ and $7.7 \%$ respectively. We have an opposite situation on the good ( 5 points) and bad ( 2 points) levels of health assessment, where the number of women exceeds that of the men by $8.3 \%$ and $1.1 \%$ respectively.

Regarding the regional indicator of health self-assessment among sexes, as compared to residents from the other cities the men from Batumi stand out $94.3 \%$ of whom assess their health as well and very well. From among the women, the highest indicator of a good health condition belongs to Khashurian females (38.9\%) and very good - to the women from Kutaisi (46.0\%). In must be noted that on the medium level (3 points) self-assessment of health, if we do not take into account the respondents from Batumi (where the women's indicator is greater than that of the men by nearly $15 \%$ ), there is not a large difference among genders according to various regions.

Therefore, it can be said that the self-assessing indicators of the certain cities' interviewed individuals' health are heterogeneous. Overall, this determined the medium indicator of the respondents' health self-assessment to be on the level of four points (more precisely on the level of 3.94 points), which speaks about a good level of their health condition.

In the same manner, health of the respondents can be assessed as good in cities where the indicator of health self-assessment varies from 3.56 (Khashuri) to 3.97 (Kutaisi). The medium point of self-assessment turned out to be equal in Tbilisi and Batumi (3.94-3.94). Nearly third of the interviewed individuals (32.8\%) suffered from this or that chronic disease (compared to the men the indicator was somewhat higher among the women $34.7 \%$ and $30.1 \%$ respectively). Fortunately, others did not manifest these kinds of symptoms. In this respect, the respondents from Batumi deemed themselves to be the healthiest - only $22 \%$ of them declared that they did not suffer from any kind of chronic illness. This indicator was approximately 1.5 times lower than the average figure of the capital (33\%) and 2.3 times lower than the figure of Khashuri (50\%).

Social upheavals always cause theories of conspiracy to come into existence (Black 2011). Hence, the same cannot be excluded in the case of the coronavirus pandemic. Our research confirmed D. Black's words. During an in-depth interview the respondents' fear toward the new coronavirus pandemic could be felt. The reasons for this were the gossips spread in mass media, as a result of unverified information, utterances of famous people (Bill Gates, etc.) which resembled the theories of conspiracy, conflicting information con-

Table 2. The level of the coronavirus threat perception, according to the respondents' aggregate groups and certain Georgian cities (\%)

\begin{tabular}{|c|c|c|c|c|c|c|}
\hline & & Tbilisi & Kutaisi & Khashuri & Batumi & Total \\
\hline \multirow[t]{5}{*}{$\begin{array}{l}\text { Below } 21 \\
\text { years of age }\end{array}$} & $\begin{array}{l}\text { Extremely } \\
\text { serious }\end{array}$ & 25.0 & 27.0 & & 47.0 & 29.0 \\
\hline & Less serious & 21.0 & 27.0 & & 7.0 & 20.0 \\
\hline & Serious & 51.0 & 7.0 & & 40.0 & 43.0 \\
\hline & Not serious & 3.0 & 40.0 & & 7.0 & 9.0 \\
\hline & Total & 100.0 & 100.0 & & 100.0 & 100.0 \\
\hline \multirow{5}{*}{$\begin{array}{l}\text { Between } 21 \\
\text { and } 60 \\
\text { years of age }\end{array}$} & $\begin{array}{l}\text { Extremely } \\
\text { serious }\end{array}$ & 32.0 & 25,0 & 39.0 & 39.0 & 31.0 \\
\hline & Less serious & 17.0 & 24,0 & 26.0 & 13.0 & 20.0 \\
\hline & Serious & 45.0 & 32,0 & 23.0 & 45.0 & 38.0 \\
\hline & Not serious & 6.0 & 20,0 & 13.0 & 3.0 & 11.0 \\
\hline & Total & 100.0 & 100.0 & 100.0 & 100.0 & 100.0 \\
\hline \multirow{5}{*}{$\begin{array}{l}60 \text { and } \\
\text { above years } \\
\text { of age }\end{array}$} & $\begin{array}{l}\text { Extremely } \\
\text { serious }\end{array}$ & 69.0 & 48.0 & 47.0 & 0.0 & 56.0 \\
\hline & Less serious & 4.0 & 18.0 & 16.0 & 0.0 & 11.0 \\
\hline & Serious & 25.0 & 27.0 & 21.0 & 100.0 & 28.0 \\
\hline & Not serious & 2.0 & 6.0 & 16.0 & 0.0 & 6.0 \\
\hline & Total & 100.0 & 100.0 & 100.0 & 100.0 & 100.0 \\
\hline \multirow{5}{*}{$\begin{array}{l}\text { All of the } \\
\text { interviewed } \\
\text { individuals }\end{array}$} & $\begin{array}{l}\text { Extremely } \\
\text { serious }\end{array}$ & 37.0 & 30.0 & 42.0 & 38.0 & 36.0 \\
\hline & Less serious & 16.0 & 23.0 & 22.0 & 10.0 & 18.0 \\
\hline & Serious & 43.0 & 28.0 & 22.0 & 48.0 & 37.0 \\
\hline & Not serious & 4.0 & 19.0 & 14.0 & 4.0 & 10.0 \\
\hline & Total & 100.0 & 100.0 & 100.0 & 100.0 & 100.0 \\
\hline
\end{tabular}


Table 3. Populations' attitude toward the infectionists' recommendations according to certain cities

\begin{tabular}{|c|c|c|c|c|c|}
\hline \multicolumn{2}{|c|}{$\begin{array}{c}\text { Fulfils infectionists' } \\
\text { recommendations }\end{array}$} & $\begin{array}{l}\text { Extremely } \\
\text { serious }\end{array}$ & Less serious & Serious & Not serious \\
\hline \multirow{4}{*}{$\begin{array}{l}\text { Constantly } \\
\text { or } \\
\text { frequently }\end{array}$} & Tbilisi & 39.1 & 13.9 & 44.5 & 2.5 \\
\hline & Kutaisi & 41.0 & 19.0 & 33.0 & 7.0 \\
\hline & Khashuri & 47.5 & 17.5 & 25.0 & 10.0 \\
\hline & Batumi & 41.3 & 10.9 & 45.7 & 2.2 \\
\hline \multirow{4}{*}{$\begin{array}{l}\text { Rarely or } \\
\text { do not } \\
\text { fulfil }\end{array}$} & Tbilisi & 0.0 & 54.5 & 0.0 & 45.5 \\
\hline & Kutaisi & 6.7 & 31.1 & 17.8 & 44.4 \\
\hline & Khashuri & 20.0 & 40.0 & 10.0 & 30.0 \\
\hline & Batumi & 0.0 & 0.0 & 75.0 & 25.0 \\
\hline
\end{tabular}

cerning the coronavirus often provided by the World Health Organization and other international organizations, ongoing recriminations between the US and China with regard to the spread of the virus in the world, etc.

As a consequence of all the afore-mentioned, world population became confused. One part of it believed in the existence of the pandemic and the threat it entailed, while the other part denied not only the menace of the pandemic, but also its very existence.

As we have already noted, the information with regard to the coronavirus delivered to a population substantially determines the perception of the virus's threat. The population is basically knowledgeable in terms of the symptoms of the Covid-19. Among the interviewed people $91.7 \%$ think that they know about the coronavirus symptoms and only $8.3 \%$ do not feel to possess relevant knowledge and information. In this regard, the women are better informed than the men about the symptoms of the virus. Among the women the share of those who are not informed about the virus's symptoms was 2.1 times lower compared to the same indicator in the case of the men (5.6\% and $12.0 \%$ respectively).

The respondents living in Batumi were the most aware of the symptoms of the coronavirus (100\%), those residing in Khashuri were the least informed (84.0\%). In this latter city the number of those individuals who did not possess data connected to the virus's symptoms almost twice exceeds the average indicator in the country ( $16.0 \%$ and $8.4 \%$ respectively).

An absolute majority of the respondents $(92.1 \%)$ reported to systematically read the data concerning the number of the infected, recovered and deceased. In spite of this, only $3 / 5$ of the interviewed people acknowledge to have fear toward the Covid-19 (60.8\%), whereas $17.8 \%$ of them think that the information about the virus is exaggerated and thus, are not afraid of it. In addition, more than $1 / 5$ of respondents $(21.5 \%)$ believe that they are not afraid of the virus because they consider themselves absolutely healthy.

The level and quality of awareness is reflected in the perception of the threat of the pandemic. From among the interviewed respondents $9 / 10$ think that the danger of the virus is serious and real in Georgia. Amid those people, 35.8\% suppose that the threat is extremely serious and only $9.5 \%$ reckon that it is not serious. It is also important to note that the fear of the coronavirus among the people with a chron- ic disease is 1.7 times higher than among those who do not suffer from any such disease ( $84.6 \%$ and $49.1 \%$ respectively).

From among the women respondents $77.5 \%$ think that the coronavirus threat is serious or extremely serious; as opposed to them, the same attitude among the males was noticed in only $66.0 \%$. Only $22.5 \%$ of the females and $34.0 \%$ of the males insist on the less seriousness or unseriousness of the threat. As we can observe, the perception level of the pandemic is heterogeneous among genders. The same can be asserted about the respondents' age and regions, which is displayed in the second table.

The perception of the pandemic threat is radically different between the young and elderly respondents. If the $72.0 \%$ of the youth aged below 21 perceive the pandemic as extremely serious (29.0\%) and serious (43.0\%), the same figure among the elderly amounts to $84.0 \%$, more than half (56.0\%) of them regard it as extremely serious and $28.9 \%$ as serious. Against the background of this, as compared to both age groups, the respondents aged 21-60 show the lower figure of the perception of the pandemic threat (69.9\%). Among the people in this latter age group $31.0 \%$ see the pandemic as extremely serious and $38.0 \%$ as serious. If the high figure of the perception of the pandemic among the elderly individuals is caused by the fact that people aged above 60 face a greater risk of becoming infected with the virus, it is hard to explain the reason behind why $29.0 \%$ of the youth aged under 21 , and $31.0 \%$ of those aged between $21-60$ think that the threat is less serious or not serious. Under the general circumstances of the pandemic an unserious attitude of the $60 \%$ of the population toward the coronavirus compels us to stop and think. The above-mentioned is exactly the main reason why the number of the infected people rose quickly in Georgia during the period after the research (from November 2020 to May 2021).

Interviewing the population unequivocally confirmed a high correlation between the perception of the threat of the Covid-19 and the levels of observance of the infectionists's recommendations. Those individuals, who regarded the virus as extremely serious, $97.2 \%$ of them, fulfilled the medics' recommendations, while among those who deemed the threat to be unserious, only $38.3 \%$ fulfilled the mentioned recommendations.

In this respect it is interesting to see what kind of situa- 
Figure 2. The level of disregarding the infectionists' recommendations by the population according to sexes and cities (\%)

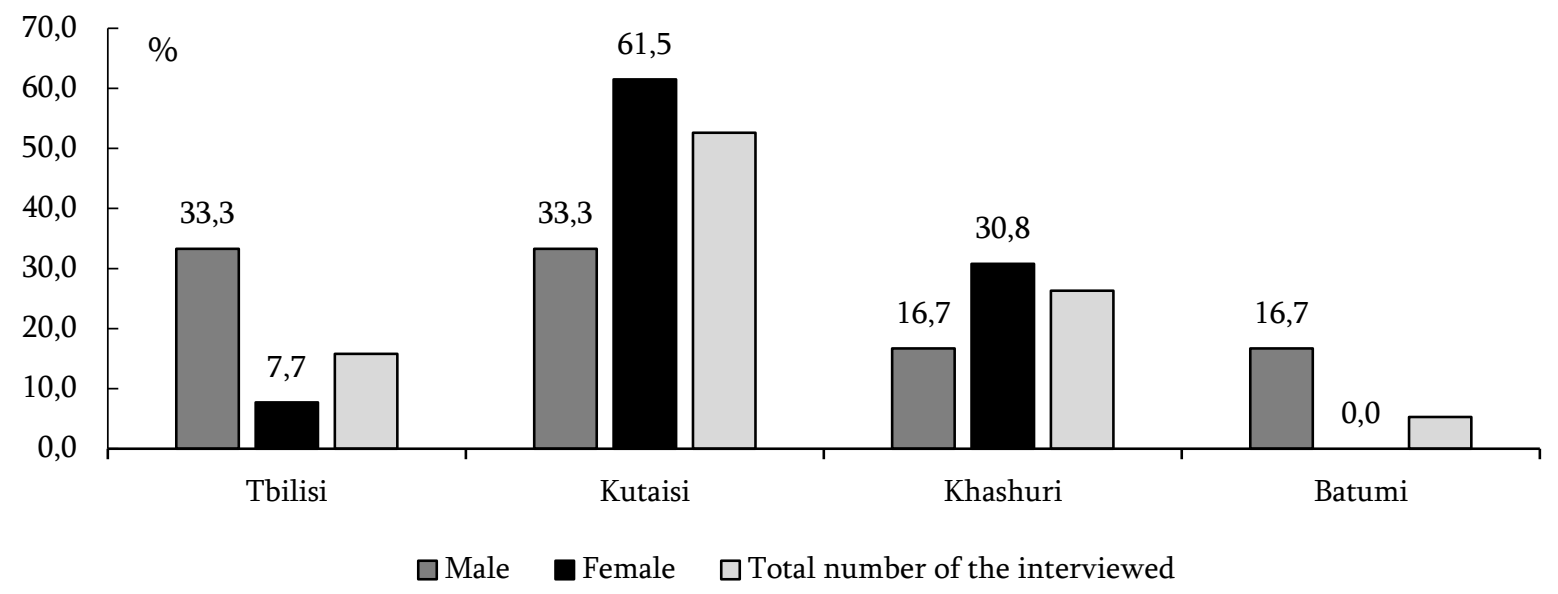

tion we have according to the selected cities, shown in Table 3. Looking at the table it becomes clear that in terms of those respondents who perceive the coronavirus threat seriously (among them extremely seriously) and consequently, constantly or often fulfill the recommendations of infectionists, we observe a better situation in Batumi (87.0\%) and Tbilisi (83.6\%). However, this figure can be deemed to be satisfactory in Kutaisi and Khashuri, where nearly 2/3 of the respondents take into account the infectionists' recommendations. With regard to "doubting Thomases", $27.5 \%$ of the Khashurians and $26.0 \%$ of the Kutaisians still observe these recommendations. The same figure is substantially lower in Tbilisi (16.4\%) and Batumi (13.1\%).

It is noteworthy that from among that portion of the respondents who look at the pandemic less seriously or unseriously, an absolute majority of the people from Tbilisi and $25 \%$ of those from Batumi do not fulfil the given recommendations. Despite the fact that they perceive the coronavirus threat to be serious, in contrast to the individuals from Tbilisi and Batumi, $24.5 \%$ of the Kutaisians and $30.0 \%$ of the Khashurians do not observe the recommendations. From among the "doubting Thomases" of these two cities $75.5 \%$ of the Kutaisians and $70.0 \%$ of the Khashurians do not observe the mentioned recommendations.

Studying the issue in certain cities, according to the respondents' sexes manifested that an equal number of the women in Tbilisi and Kutaisi (33.3\%) do not take into account the medics' recommendations. The level of disregard of the recommendations is equal among the women from Khashuri and Batumi (16.7\%) as well, however, their figure is twice less than the level of disregard of the recommendations among the interviewed women from Tbilisi and Kutaisi. As regards the level of disregard of the infectionists' recommendations by the men, except from those living in Kutaisi and Khashuri, the same figure of the men in the rest of the two cities significantly lags behind the corresponding figure of the women, and the men in Batumi do not observe the recommendations at all. Under these circumstances, the levels of disregard of the recommendations by the men in Kutaisi and Khashuri, despite their dissimilar figures, exceeds nearly twice the level of the women residing in the same cities.

The sincerity of the respondents (especially Kutaisian men) is confirmed by the fact that, despite realizing the necessity of fulfilling the medics' recommendations in order to fight against the Covid-19 by an absolute majority of the respondents, they still did not adhere to them or fulfilled them less. With regard to observing the medical-hygienic recommendations, the women interviewees displayed much more responsibility and discipline compared to their male counterparts. From among the women only $9.1 \%$ did not observe the recommendations at all or did so rarely and the same figure for the men was $20.8 \%$ (on average $-14.1 \%$ ).

The in-depth interview also confirmed the negative consequences of ignoring the medics' recommendations. Name-

Figure 3. The level of disregard of the infectionists' recommendationsby the population

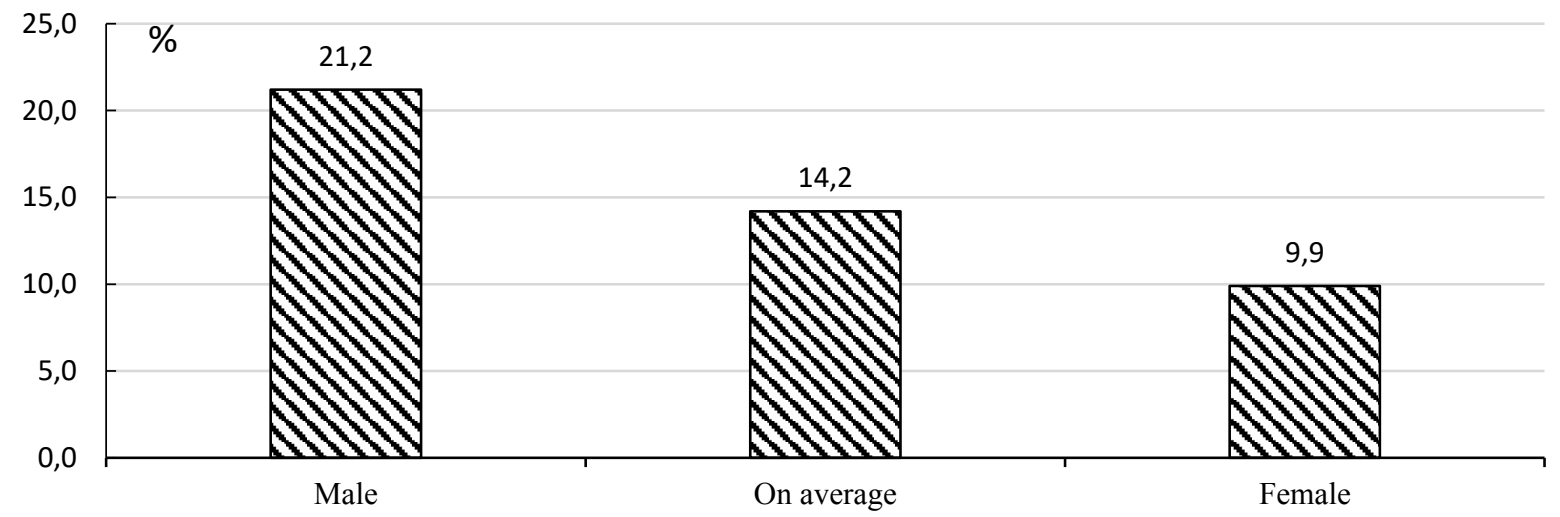


Table 4. Subsidization of the communal expenses of the households is deemed to be the most successful measure (Percentage from the total number of the respondents)

\begin{tabular}{|c|c|c|c|c|c|}
\hline & Georgia & Tbilisi & Kutaisi & Batumi & Khashuri \\
\hline Percentage & 90.2 & 96.1 & 84.6 & 97.1 & 75.0 \\
\hline
\end{tabular}

ly, among the respondents' relatives (family member, relative, and acquaintance) those who did not observe the recommendations faced 5 times more occurrences of infection than those who did observe the medics' recommendations.

It is true that the absolute majority of the interviewed people reckon that they fulfill the recommendations given by the infectionists (96.2\%), however, only half of them do so constantly, which must also be included as one of the important conditions for spreading the virus. Additionally, the share of those respondents who constantly fulfil the mentioned recommendations among those who suffer from a chronic illness is 1.7 times higher than among those individuals who are not inflicted by the chronic illness (64\% and 38\%, respectively; on average $-46 \%)$. In this regard to the women take more responsibility for observing the doctors' recommendations than their male counterparts. Among the female respondents the level of disregarding the recommendations is 2.1 times lower than the analogous figure of the males.

Among the number of recommendations coming from doctors the respondents most of all (frequently) pay heed to the advice of wearing a mask in the closed space and areas of public hangout (approximately $46.8 \%$ ); recommendations that are least observed include curbing mass gatherings, social distancing (10.2\%) and spraying one's hands with an antiseptic liquid (12.6\%).

We can conclude that an undesirable self-caring behavior of the population established under the conditions of Covid-19 has significantly contributed to the rise of the cases of the coronavirus infection and subsequent instances of death during the period after the research (since November 2020 until today).

Despite the important anti-pandemic measures undertaken by the government (lockdown, preventing sport and cultural events and banquets, inoculation, restricting the work of public transportation, etc.), it was exactly the incor- rect self-caring behavior of the population that determined the third wave of the pandemic in April-May of 2021.

Among the respondents $41.5 \%$ think that the measures, implemented by the Georgian government in order to overcome the losses incurred as a result of the pandemic, were adequate to the scales of the loss. At the same time, only $5.9 \%$ of the respondents reckon that the mentioned measures exceed the scales of the loss. This latter figure is 6 times lower than the number of those in whose opinion the government measures substantially lag behind the scales of the loss. Moreover, almost half of those respondents who think that the measures undertaken by the government were adequate to the scales of the loss also view the Covid-19 threat as serious and the figure of that contingent for whom the virus does not pose a serious threat (or any kind of threat, for that matter) is only $21.5 \%$.

According to the $76.7 \%$ of the respondents, the most successful step of the Georgian government in alleviating the losses to the country's economy caused by the coronavirus and among its anti-crisis measures was subsidizing the communal expenses of households.

Furthermore, the level of positive assessment is in high correlation with the urbanization level of the respondent's center of population. Taking into account the mentioned circumstance, the level of positive assessment of the communal expenses is especially high in modern Tbilisi and Batumi which are loaded urban-wise and in less loaded Khashuri (table 4).

The second place was occupied by the program under the auspices of which the government gave 200-GEL aid to the children aged below 17 (69.4\%), and the third - monetary assistance provided for the unemployed (51.4\%). In as much as the respondents could name several successfully implemented measures, the sum of such measures amounted to a number higher than 100 percent.

Economic crisis caused by the coronavirus did some damage to the $76.1 \%$ of the interviewed individuals; only every fourth household survived losses. According to the population centers, the highest level of damage was confirmed in Kutaisi (more than $9 / 10$ of the respondents), the lowest - in Batumi (44.0\%).

It must be noted that more than a quarter of the respondents lost a job due to the Covid-19 (27.2\%), however, the

Figure 4.The most successful measures (From the total number of the respondents)

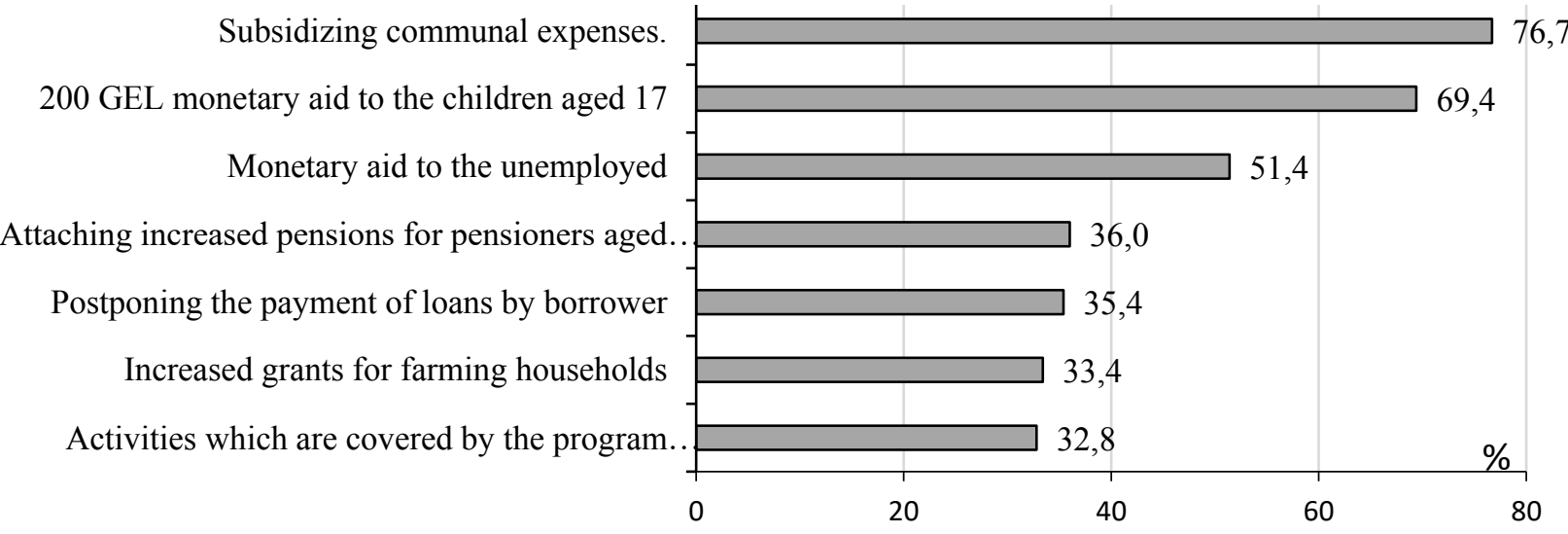


Figure 5. The share of the respondents who faced damages from the economic crisis caused by the coronavirus in the total number of the interviewed individuals

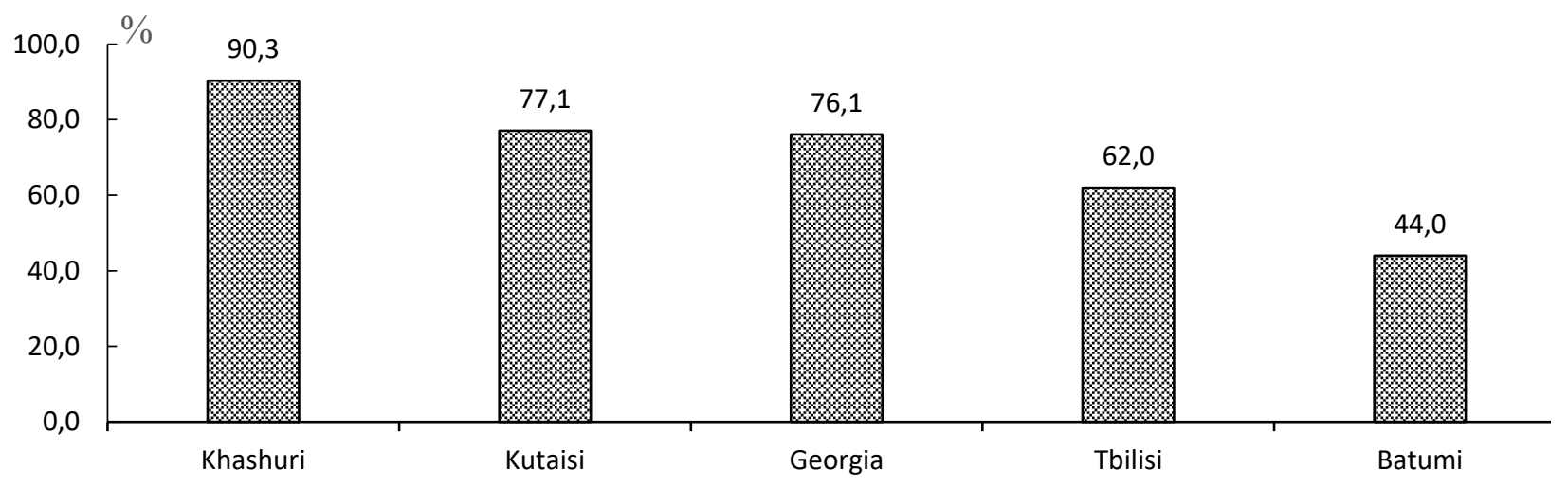

number of those people who did not lose the job but had to move to a part-time labor or receive a lower salary hourly is nearly twice as much (53.4\%).

A fairly large number of the population $(30.4 \%)$ could not pinpoint the time when their family's income would arrive at the pre-crisis 2019 level. From among the interviewed individuals $17 \%$ think that not even two years will be sufficient for their income to reach the pre-crisis level, and $17.4 \%$ reckon that their family's income will never reach the 2019 level ever. In this respect, the respondents from Batumi are the most optimistic (44\% of them think that their family's economic situation will arrive at the pre-crisis level in less than 1 year; for comparison - on average, only $19.4 \%$ think so in the whole country). The most pessimistic attitude was noticed among the Khashurians, where the share of the respondents who have a pessimistic disposition and are left in an uncertain situation is the highest (figure 6).

The interview has revealed one more important trend: the better the respondent's health condition the more optimistic is the assessment of the economic perspective of their own household. For instance, among those respondents who assessed their health with five points (using the 5-point assessment system) the assumption that the deteriorated economic situation of their households caused by the crisis will return to the pre-crisis 2019 level exceeds 4 times the analogous prognosis of those individuals who assessed their health condition with three points (table 5).
Furthermore, despite the perception of the Covid-19 threat by the respondents, the economic crisis caused by the pandemic influenced three out of every four people equally negatively. In spite of their age, the economic situation of these respondents deteriorated because of the coronavirus. On top of that, those families which had a direct or indirect contact with the infected individuals experienced, to a certain degree, higher losses brought about by the crisis than those families that did not have the same kind of contact with the infected ( $85 \%$ and $72.9 \%$ respectively; on average $-76.1 \%$ ).

Sex, age and regional structure of the Georgian population were taken into consideration during the interview. This makes the received data quite objective and representative.

The individuals who had a direct or indirect contact with the infected people observe the infectionists' recommendations considerably more. The indicator of observing the recommendations among those people who had contact with the infected is nearly 1.5 times greater than the same indicator of that contingent who did not have any kind of contact whatsoever with the infected ( $60.9 \%$ and $41.6 \%$ respectively).

The above-mentioned research not only provides us with firm and unbiased information regarding the spread of the coronavirus, the quality of the population's perception of the threats coming from the virus and their reaction, but it also has a practical value for the government in formulating and increasing effectiveness of anti-pandemic and anti-crisis packet of measures.

Figure 6.In the respondents' opinion, their family's income at the level of the pre-crisis 2019 period

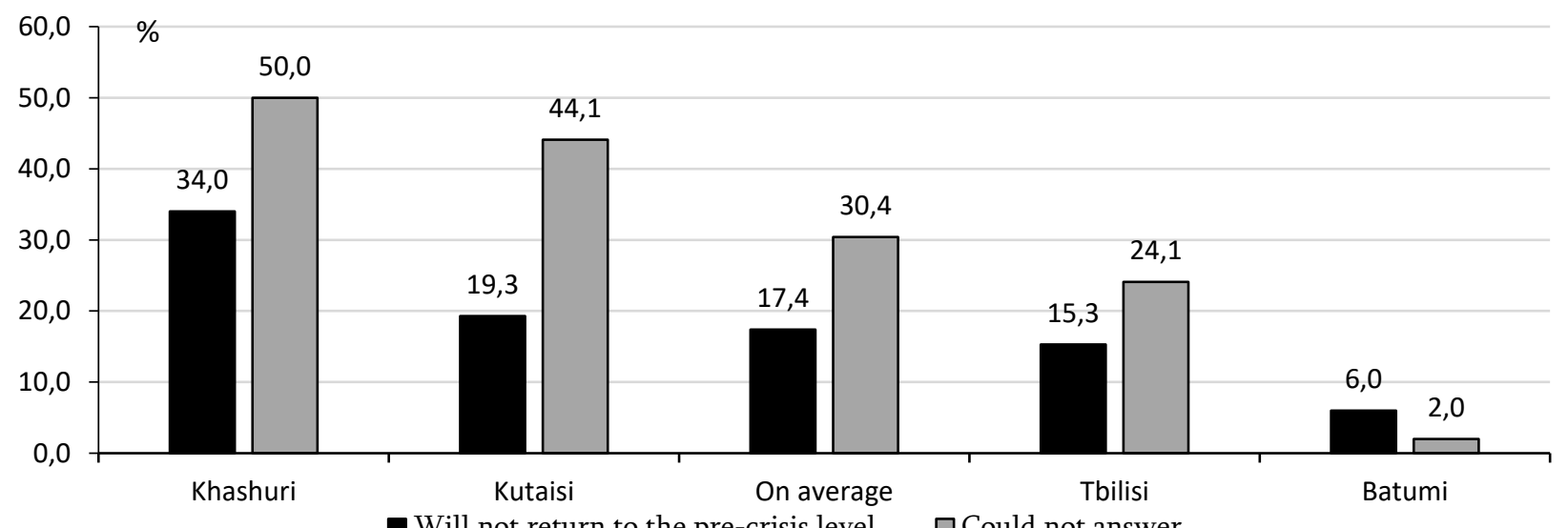

Will not return to the pre-crisis level $\square$ Could not answer 
Table 5.The economic condition of the households will arrive at the pre-crisis 2019 level (\%)

\begin{tabular}{|c|c|c|}
\hline & $\begin{array}{c}\text { Within the } \\
\text { nearest } 6 \text { months }\end{array}$ & $\begin{array}{c}\text { Will not return to the pre- } \\
\text { crisis condition }\end{array}$ \\
\hline $\begin{array}{l}\text { Assess their health with } \\
\text { a 5-point system }\end{array}$ & & \\
\hline$-\quad 3$ points & 11.1 & 29.1 \\
\hline$-\quad 5$ points & 41.7 & 27.9 \\
\hline
\end{tabular}

\section{CONCLUSION}

Despite the fact that the pandemic is still raging and the medics and epidemiologists have already announced the "fourth wave" in autumn, we can still draw some conclusions:

Firstly, the period between the waves is approximately 3-4 months, during which time the quantity of the cases in terms of the infected and deceased stays at the stable level;

Secondly, each wave in Georgia was specific when its negative effect had varying dimensions from the medical and economic standpoints. During the first wave of the pandemic the economy of the country suffered the most, while the second wave damaged the sphere of healthcare and the third impacted, more or less, the both fields. For example, in May 2021 the average round the clock amount of the infected people increased 3.5 times compared to March, whereas the number of the deceased increased 2.5 times. "In exchange", the mentioned period brought about the revival of the economy and an unprecedented growth of export.

Thirdly, the "third wave" (and subsequent "waves") will/ can not have the same negative power as the previous ones because the country has successfully implemented and is carrying out the general inoculation process of its population.
Fourthly, in spite of the fact that the women are more cautious and disciplined in terms of the coronavirus, they have a substantially higher incidence rate than the men. Namely, from among the total number of the infected in $2020,57 \%$ were women and $43 \%$ - men.

Fifth, 2528 people died from the coronavirus in Georgia in 2020 which is $5.0 \%$ of the total number of deaths that year and only $1.1 \%$ of the people ill and dead from the Covid $-19^{2}$.

We must locate the main reason for the rapid growth of the cases of infection in Georgia during the period after the research (from November 2020 to May 2021) in quite a high number of those people who adopt a puerile and unserious attitude toward the Covid-19 (39.3\% of the respondents).

The research has confirmed that no less than 9 individuals have a direct and indirect contact with a single infected person. This must be deemed to be one of the important factors for spreading the virus. Therefore, along with the efforts of the medical personnel, citizens' responsibility and observance of preventive measures have to play a significant role in fighting against the pandemic. Massive inoculation and observing preventive and hygienic measures are among those basic devices which determine the final strategy of victory over the Covid-19.

${ }^{2}$ For comparison: lethality figures of the Covid-19 in some other countries, according to the December 31, 2020 data amounted to: in Mexico $-8.82 \%$, in China - 5.32\%, in Australia - 3.20\%, in Sweden - 2.03\%, in Armenia - 1.77\%, in the USA - 1.73\%, in Azerbaijan - $1.41 \%$, in Turkey 0.95\% (one year with the Covid-19. 2021: 27)

\section{REFERENCES:}

A sociologicalresearch of the IliaStateUniversity'sInstitute of Demography and Sociology - About the impact of the coronavirus pandemic on the social-economicsituation of Georgian population in connection with awareness and self-preservative behavior. October, 2020.

Abesadze, R., (2020). Globalization and economic problems of the pandemic. J. "Economics and Business". № 2:31-36. (In Georgian).

Archvadze, J., (2020). Global changes associated with the coronavirus pandemic (political-economic aspect). Tbilisi, "Mtsignobari". (In Georgian).

Beck, U., (2000).What is globalization? Cambridge, England: Polity Press,

Bedianashvili, G., Maglakelidze, A. (2021).The Digital Economy and Business in the Conditions of Pandemic. The materials of the International Scientific Conference: Social Sciences for Regional Development 2020. Part III. Issues of Economics:26-37.

Black, D., (2011). Moral time. Oxford University Press, USA.

Capriano, R. M., (2020). Sociologist explains how coronavirus might change the world around us. https://phys.org/news/202004-sociologist-coronavirus-world.html. 
Charaia, V., (2020). Coronomics - a threat or an opportunity?! "Economics and Business". № 2:68-71. (In Georgian).

Cohan, D. J., (2020). Sociology of the virus assignment.

Fitzpatrick, K., (2020). Survey shows regions of elevated food insecurity due to COVID-19 pandemic. https://news.uark.edu/ articles/52820/survey-shows-regions-of-elevated-food-insecurity-due-to-covid-19-pandemic.

Gigerenzer, G., (2020). Why What Does Not Kill Us Makes Us Panic". Project Syndicate, 2020, March 12. www.project-syndicate. org/commentary/greater-risk-literacy-can-reduce-coronavirus-fear-by-gerd-gigerenzer-2020-03.

Gomelauri, N., (2020). Georgia in the thirdperiod of epidemiologictransition. Proceedings of Materials of International Scientific Conference. Current Economy, Economic Science and Pandemic Problems of Economy: The Challenges and Ways of Finding Solution:172-177. (In Georgian).

Grmek, M.D., (1994). Las maladies a l'aube de la civilization occidentale. Paris.

Jibuti, M., (2020). Viral variations of politeconomy. "Economics and Business". № 2:37-43. (In Georgian).

Mekvabishvili, E., (2020). The impact of the global Coronomic crisis on the Georgian economy (instead of preface). "Economics and Business". № 2:9-13. (In Georgian).

Omran, A. R., (1971). The Epidemiologic Transition. A Theory of the Epidemiology of Population Change. "The Milbank Memorial Fund Quarterly," Vol. 49 (4):355-391, New-York.

One year with COVID-19. The report of the National Center for Disease Control and Public Health. $5^{\text {th }}$ edition. $2021: 27$.

Papava, V., (2020). Coronomic Crisis: When The Economy Is A hostage To Medicine. Eurasia Review. Journal of Analysis and News, March 29, https://www.eurasiareview.com/29032020

Papava, V., (2020). Coronomics and essentially new economic crisis. J. "Economics and Business". № 2:13-16. (In Georgian).

Papava, V., Charaia V. (2020). The Coronomic Crisis and Some Challenges for the Georgian Economy. No 136. GFSIS. Opinion papers. https://www.gfsis.org/publications/opinion-papers

Prince Kennex R. Aldama. Using sociology to make sense of the coronavirus pandemic. https://www.rappler.com/views/ imho/255954

Sulaberidze, A., (2020). Pandemology - the newest field of science?! Institute of Demography and Sociology Ilia State University. scollection of works "problems of demography and sociology":135-150. (In Georgian).

Sulaberidze, A., (2021). On Formation and Development of Pandemology as an Interdisciplinary Branch of Science. "Economics and business". № 1.

Tsuladze, G. and Sulaberidze, A., (2015). Fundamentals of demography. Textbook Ilia State Universite Press:62. (In Georgian).

Tvalchrelidze, A. and Silagadze, A., (2020). COVID-19 The impact of the COVID-19 Coronavirus pandemic on the price of crude oil, preliminary statistical analysis. Economics and Business". № 2:2-89. (In Georgian). 